Asian J. Med. Biol. Res. 2020, 6 (1), 56-66; doi: 10.3329/ajmbr.v6i1.46479

\author{
Asian Journal of \\ Medical and Biological Research \\ ISSN 2411-4472 (Print) 2412-5571 (Online) \\ www.ebupress.com/journal/ajmbr
}

\title{
Article \\ Effects of foliar and root application of epsom salt on aquaponics beetroot (Beta vulgaris) production in confined condition
}

\author{
Shamima Akter ${ }^{1}$, Alif Layla Bablee ${ }^{1}$, K. M. Shakil Rana ${ }^{1} *$, Mahbuba Nigar ${ }^{1}$, Zubyda Mushtari Nadia ${ }^{1}$ and M. \\ A. Salam ${ }^{1}$ \\ Department of Aquaculture, Bangladesh Agricultural University, Mymensingh-2202, Bangladesh \\ ${ }^{*}$ Corresponding author: K. M. Shakil Rana, Assistant Professor, Department of Aquaculture, Bangladesh \\ Agricultural University, Mymensingh-2202, Bangladesh. Phone: +8801728300299; E-mail: \\ ranakms@bau.edu.bd
}

Received: 05 February 2020/Accepted: 19 March 2020/ Published: 31 March 2020

\begin{abstract}
The study was conducted to evaluate the impact of epsom salt, rich in magnesium and sulfur content beneficial to plant, on beetroot production in aquaponics system. Media based aquaponics systems (nine units) were employed for beetroot and tilapia culture where three treatments $T_{1}, T_{2}$ and $T_{0}$ were applied with three replications $\left(R_{1}, R_{2}\right.$, and $\left.R_{3}\right)$ each. Epsom salt was applied in $T_{1}$ as foliar spray in the form of $5 \%$ solution in each replication, whereas same amount of epsom salt $(5 \mathrm{~g})$ was directly applied on vegetable bed in $\mathrm{T}_{2}$ as root application. But in control $\left(\mathrm{T}_{0}\right)$ no epsom salt was used. Beetroot saplings were planted in retrospect at a rate of two saplings per growbed (replication). After thirty days, plants grew enough to support the water clarification in aquaponics, ten tilapia fry were stocked per tank $(90 \mathrm{~L})$ in each replication. Fish were fed commercial floating feed containing $30 \%$ protein. Although the fish growth parameters in three treatments were statistically similar, the highest mean length gain, weight gain, specific growth rate and fish production were found $5.11 \pm 1.64 \mathrm{~cm}$, $30.16 \pm 0.11 \mathrm{~g}, 0.39 \pm 0.01 \% /$ day and $26.27 \pm 2.47$ tons/ha/60 days respectively in $\mathrm{T}_{1}$ followed by $\mathrm{T}_{2}$ and $\mathrm{T}_{0}$. However, response of beetroots to different treatments was statistically different. The highest average leaf area $\left(69.79 \pm 0.48 \mathrm{~cm}^{2}\right)$, length of root $(31.03 \pm 0.43 \mathrm{~cm})$, weight of root $(21.17 \pm 1.92 \mathrm{~g})$, and production of beetroot $8.67 \pm 1.54$ tons/ha/90 days were found in $\mathrm{T}_{1}$ followed by $\mathrm{T}_{2}$ and $\mathrm{T}_{0}$. Harvesting time was also reduced in epsom salt based aquaponics system. The overall production of beetroot and tilapia was higher in $\mathrm{T}_{1}$ (foliar spray) than $\mathrm{T}_{2}$ (root application) and $\mathrm{T}_{0}$ (control). Thus, the study signifies the potentialities of epsom salt in aquaponics vegetable production. However, further research is needed to verify the dose response to epsom salt in aquaponics system.
\end{abstract}

Keywords: aquaponics; epsom salt; foliar application; root application; beetroot

\section{Introduction}

Aquaponics, a perfect engineering of ecology, is the combination of aquaculture (fish or crustaceans) and hydroponic cultivation of plants (soilless production) in a re-circulating system, utilizing the nutrients present in the aquaculture effluents to produce plants with commercial value (Yildiz et al., 2017). Catastrophic climatic change, reduced agricultural land and demand of safe food gradually transfer aquaponics technology to an essential part of life for producing organic food at our dwelling.

Beetroot (Beta vulgaris) is generally known as garden beet. It is native to Mediterranean region but is widely cultivated in America, Europe and throughout Indian subcontinent. It is being traditionally used in medicine, specifically for the treatment of fertility, cancer, hypertension and urinary tract disorders (Chawla et al., 2016). It makes a wonderful dietary supplement being not only rich in nutrients, minerals, amino acids and vitamins but also has unique phyto-constituents, which have numerous medicinal properties such as anti-oxidant, antidepressant, anti-microbial, anti-inflammatory, diuretic and expectorant properties. It is one of the natural foods, 
which boosts the energy to athletes. It is also used as natural food color in dairy and meat products. Traditionally, beetroot is consumed as food and has high nutritive value. It is now being recognized as a functional food (Ninfali, 2013). Beetroot contains alkaloids (128.889), steroids (16.4), glycosides (0.652), flavonoids (6.417), terpenoids (115.5), saponins (3.789), and acidity level (5.227) all in $\mathrm{mg} / 100 \mathrm{~g}$. The elemental analysis of Beta vulgaris includes the presence of the following minerals: iron, magnesium, copper, sodium, potassium, manganese, calcium and zinc in the ratio $0.76,18.60,0.08,73.60,31.20,0.86,13.80$ and 0.29 $\mathrm{mg} / 100 \mathrm{~g}$ respectively. Vitamins were also analyzed as vitamin A $(2.6 \mu \mathrm{g} / 100 \mathrm{~g})$, vitamin $\mathrm{K}(3.2 \mu \mathrm{g} / 100 \mathrm{~g})$, vitamin $C$, vitamin $E$, vitamin $B_{3}$, vitamin $B_{6}$, vitamin $B_{2}$, pantothenic acid and cholesterol $4.36,0.18,0.35$, $0.03,90.053,0.034,0.151$ and $0.04 \mathrm{mg} / 100 \mathrm{~g}$, respectively (Odoh and Okoro, 2013). Because of these potentialities, beetroot was attempted to culture in aquaponics system.

However, aquaponics has some limited nutrients supply as it lake the traditional soil growbed. Several efforts have been made to supplement aquaponicsally grown plants with nutrients (Bethe et al., 2017; Zahan et al., 2018). As a continuation of the endeavor, epsom salt $\left(\mathrm{MgSO}_{4} .7 \mathrm{H}_{2} \mathrm{O}\right)$ has been selected to supply additional minerals in this system. Plants require seventeen essential nutrients for proper development among which magnesium and sulfur are two commonly deficient macronutrients that could be supplemented to plants with epsom salt (hydrated magnesium sulfate) (Kristek et al., 1997; Epstein and Bloom, 2005).

Epsom salt was chosen due to its high solubility in water, vital elements for plant growth, quick nutrient uptake by plants, traditional use as plant fertilizer and ease application as foliar spray. Epsom salt is not true salt, but it is known as a salt due to its chemical structure. It consists of mixture of magnesium and sulfur. In water epsom salt dissociates into magnesium ions, and sulfate ions. These ions are easy to absorb through the plant cell and improves the benefits of epsom salt. Magnesium and sulfur play a vital role in the plant physiology by regulating the enzymatic activity. In practical, magnesium induces chlorophyll synthesis and sulfur activates that chlorophyll for photosynthesis in plants. Besides, these two minerals improves nutrients (mostly nitrogen and phosphorous) absorption capacity in plant, therefore increase plants' ability to produce flowers and fruits. Consequently, using epsom salt promises a bushier and greener garden (Orlovius, 2001; Merhaut, 2007; Tilley 2016; Elbossaty, 2018)

In order to assure favorable plant growth, nutrients must be available not only in sufficient amounts, but also in appropriate ratios (Maathuis, 2009). Foliar spray is an effective way to avail nutrients for plant growth. As for examples, foliar spray of $30 \%$ magnesium $(\mathrm{Mg}$ ) solution rectified $\mathrm{Mg}$ deficiency in tea plants within 14 days of spraying and the growth rate increased by 16 to $13.45 \%$ whereas a $20 \% \mathrm{Mg}$ solution could only correct the insufficiency after a second application (Obatolu, 1999). In another research, foliar spray of 5\% epsom solution on sugar beets increased sucrose contents by 0.25 and $0.20 \%$ (Kristek et al., 1997). In aquaponics, foliar spray of molasses and compost tea also yield increased production of water spinach (Bethe et al., 2017).

Therefore, the present experiment was conducted to assess the effects of epsom salt as foliar spray and root application on beetroot production in aquaponics system. Notably, monosex tilapia (Oreochromis niloticus) was preferably selected to culture in aquaponics system because of hardy and fast growing features of the fish species (Rakocy et al., 2011).

\section{Materials and Methods}

\subsection{Site selection}

The experiment was conducted at the Aquaponics Laboratory (Aquaponics Oasis), Department of Aquaculture, Faculty of Fisheries, Bangladesh Agricultural University (BAU), Mymensingh from $17^{\text {th }}$ february to $18^{\text {th }}$ May, 2018.

\subsection{Experimental design}

The experimental design was comprised of nine sets of aquaponics unit where nine fish holding tanks (diameter $58 \mathrm{~cm}$, height $45 \mathrm{~cm}$ ) each containing 120 liter of water and nine plastic containers for vegetable growing beds (38.5 cm length, $28.5 \mathrm{~cm}$ width, $22 \mathrm{~cm}$ height) were installed.

There were two treatments $\left(\mathrm{T}_{1}\right.$ and $\left.\mathrm{T}_{2}\right)$ with epsom salt application (foliar spray and direct application on plant grow bed respectively) and a control $\left(T_{0}\right)$ with no epsom application. Each treatment $(T)$ were applied on three separate aquaponics unit as replication (R), therefore denoted as $T_{1} R_{1}, T_{1} R_{2}, T_{1} R_{3}, T_{2} R_{1}, T_{2} R_{2}, T_{2} R_{3}, T_{0} R_{1}, T_{0} R_{2}$ and $\mathrm{T}_{0} \mathrm{R}_{3}$ Which were placed randomly (Figure 1).

\subsection{Bed preparation for beetroot cultivation}

Plastic containers which were locally available, cheap and good quality used as beetroot culture beds (plant growbeds). Each container ( $38.5 \mathrm{~cm}$ length, $28.5 \mathrm{~cm}$ width, $22 \mathrm{~cm}$ height) was cut longitudinally $1.27 \mathrm{~cm}$ inch 
below from the upper surface to make it a bed, cleaned with detergent, rinse with clean water for 3 to 4 times and sun dried before use. A hole was made above 0.5 inch from the bottom to facilitate clean water passage from the beetroot bed to the fish tank. Each grow bed was filled with brick lets of $2-5 \mathrm{~cm}$ sizes as plant growing substrates. The plastic containers were placed on a wooden structure for convenient management.

\subsection{Planting beetroot saplings}

For production of beetroot saplings first the seeds were soaked for 24 hours. Then these were replaced to a plastic bucket containing 50\% coco dust and 50\% vermi-compost and covered with paper. Before that a pore was created into the plastic bucket 0.5 inch above the bottom for emergency water exit. After germination 2 saplings were planted in two opposite corners of each growbed.

\subsection{Application of Epsom salt}

Locally available epsom salt was collected and prepared for application in $\mathrm{T}_{1}$ and $\mathrm{T}_{2}$. In $\mathrm{T}_{1}, 5 \%$ epsom salt was applied as foliar spray on beetroot plants of each replication (R). Foliar spray for each plant growbed was prepared by dissolving $5 \mathrm{~g}$ of epsom salt in filtered water to make the final volume $100 \mathrm{ml}$ and sprayed on plants fortnightly. Whereas, $5 \mathrm{~g}$ of epsom salt was applied directly on each growbed fortnightly in $\mathrm{T}_{2} . \mathrm{T}_{0}$ was control, therefore no epsom was supplemented. The concentration of epsom salt was selected according to Kristek et al., 1997.

\subsection{Fish tank preparation}

Nine fish holding tanks (diameter $58 \mathrm{~cm}$, height $45 \mathrm{~cm}$ ) with the volume of $90 \mathrm{~L}$ of water were used for fish culture. The tanks were prepared by washing, drying, setting up pipes, filling up with water. The tanks were brought from local market. At first tanks were uncovered and then these were washed with disinfectant to remove chemicals if any. An 18 watt submersible pump for watering the vegetables and one air pump with two air stones for oxygen supply were set in each aquaponics unit.

\subsection{Stocking and rearing the fish}

Monosex tilapia (Oreochromis niloticus) were collected from a renowned hatchery. During transportation oxygenated polythene bags that contained $2 / 3$ oxygen and $1 / 3$ water was used. Acclimatization helps to minimize stress of fingerlings and to adapt with the differences of water temperature, $\mathrm{pH}$, and oxygen between the transported bag and the fish tank water. For acclimatization, the polythene bag containing fish was kept in fish tank for one hour to reduce temperature difference between polythene bag and fish tank. After acclimatization the bag was untied and created current by hand so that the fish can move freely into the tank. The fish which could not swim freely against water current was discarded. Ten fish were stocked in each tank containing $90 \mathrm{~L}$ of water. Fish were stocked after thirty days of beetroot plantation to allow beetroot sapling grow enough to support the recirculation process in aquaponics.

\subsection{Fish and vegetable sampling and harvesting}

Fish and vegetables were sampled fortnightly. During each sampling, 10\% fish of each tank (each replication) were caught randomly with scoop net and individual length-weight was measured with an electronic compact balance and wooden measuring scale to ascertain fish growth performance. Number of leaves, leaf area, length and weights of plants and roots were also recorded during each sampling. All data were recorded in notebook. After recording length and weight, fish were released in respective tank. After 90 days of experiment, fish and beetroots were cropped on the day of final harvest.

\subsection{Water quality parameters}

Physico chemical parameters of tank water were measured to know the suitability of fish culture. Temperature, DO (dissolved oxygen) and $\mathrm{pH}$ were measured every 7 days interval. Electric conductivity (EC), carbonate $(\mathrm{CO} 3)$, hydrogen carbonate $(\mathrm{HCO} 3)$, potassium $(\mathrm{K})$, total nitrogen $(\mathrm{N})$, sulfur $(\mathrm{S})$ and sodium $(\mathrm{Na})$ content of aquaponics water were also measured at monthly interval. The tests were done in the Humboldt Soil Testing Laboratory, Soil Science department, Bangladesh Agricultural University.

\subsection{Data processing and analysis}

The data were processed for analysis using "Microsoft Excel 2010". The collected data were summarized carefully before final tabulation. Data were analyzed by using one way analysis of variance (ANOVA) and Duncan's new multiple range test (DMRT). R-Stat software was also employed to visualize the significance of 
the treatments. Final results have been depicted in tabular and graphical forms.

\section{Results and Discussion}

\subsection{Plant growth parameters}

The growth of beetroot plants was measured at different sampling date throughout the study period and production of beetroot was obtained at final harvest.

The highest mean height of the plant was $64.8 \pm 2.65 \mathrm{~cm}$ in $T_{1}$ followed by $59.17 \pm 4.75 \mathrm{~cm}$ and $43.68 \pm 1.71 \mathrm{~cm}$ in $\mathrm{T}_{2}$ and $\mathrm{T}_{0}$. The epsom salt effects might be the possible reasons for significant differences of plant height among the treatments. Salam et al. (2014) found the highest $85.58 \pm 1.53 \mathrm{~cm}$ of tomato plant height and Parvin (2016) obtained the highest taro plant height of $75.71 \pm 20.15 \mathrm{~cm}$ in aquaponics system. The height of beetroot in the present study was less than the other research findings which might be due to species variation.

The highest mean leaf number, leaf area and weight of leaf were observed during the final harvest valued as $9.53 \pm 0.15,69.79 \pm 0.48 \mathrm{~cm}^{2}$ and $41.91 \pm 2.41 \mathrm{~g}$ respectively in $\mathrm{T}_{1}$ whereas the lowest values were $7.99 \pm 0.18$, $50.52 \pm 0.81 \mathrm{~cm}^{2}$ and $31.08 \pm 3.11 \mathrm{~g}$ respectively that obtained in $\mathrm{T}_{0}$. Notably, there were significant differences in mean leaf number, leaf area and leaf weight of beetroot plants among the treatments (Table 1).

Root length and weight were also measured on the final harvesting date. The significantly highest length and weight of roots were $31.03 \pm 0.43 \mathrm{~cm}$ and $21.17 \pm 1.92 \mathrm{~g}$ obtained in $\mathrm{T}_{1}$ followed by $\mathrm{T}_{2}$ and $\mathrm{T}_{0}$ whereas the lowest were found $19.48 \pm 1.63 \mathrm{~cm}$ and $14.24 \pm 1.01 \mathrm{~g}$ in $\mathrm{T}_{0}$ (Table 1). Remarkably, the differences among the mean values of the parameters were significant therefore suggesting positive effects of epsom salt on the plants wellbeing.

The highest and lowest weight of beetroot plants were $160.11 \pm 1.51 \mathrm{~g}$ in $\mathrm{T}_{1}$ and $129.06 \pm 3.05 \mathrm{~g}$ in $\mathrm{T}_{0}$ respectively (Table 1). Salam et al. (2014) found that the plant weight of tomato in aquaponics system was $109.59 \pm 116.72 \mathrm{~g}$, even as Afrin (2018) found the highest weight of cauliflower plant $170.43 \mathrm{~g}$ in aquaponics system which has similarity to the present findings.

\subsection{Beetroot production}

The highest and lowest individual mean weights of harvested beetroot were $95.28 \pm 6.40 \mathrm{~g}$ and $73.87 \pm 2.71 \mathrm{~g}$ in $\mathrm{T}_{\mathbf{1}}$ and $\mathrm{T}_{0}$ respectively (Table 1). This might be due to the epsom salt effects on beetroot production as Elamin and Wilcox (1985) also concluded that tomato production was increased by $27.9 \%$ with $\mathrm{Mg}$ application.

Similarly, the significantly highest beetroot production was obtained in $\mathrm{T}_{1}$ figured as $8.67 \pm 1.43$ tons/ha/90 days. Whereas $\mathrm{T}_{2}$ produced $7.48 \pm 2.71$ tons/ha/90days which was also significantly higher than $\mathrm{T}_{0}(6.61 \pm 1.82$ tons/ha/90days) (Figure 2). As because all other growth factors were maintained similar in all the treatments over the study period, it could be concluded that addition of epsom salt raised the beetroot production and improved plants' wellbeing. And foliar spray of epsom is much effective than direct application on growbeds. Similarly, Bethe et al. (2017) also concluded that foliar spray with compost tea and molasses had positive impacts on aquaponicsally grown water spinach (Ipomoea aquatica) than no spray in control. Although not certain, but foliar spray might effects more positively as it is applied on plant leaves and stems directly whereas in growbed application roots are responsible for mineral transportation to other parts of plants. Therefore, foliar spray in $T_{1}$ might have better effects on beetroots than direct growbed application of epsom salt in $T_{2}$. However, Anna and Maria (2013) carried out a field experiment with beetroot employing conventional, integrated and organic methods and found production of $16.14,29.42$ and 28.80 tons/ha/90 days in conventional, integrated and organic methods respectively. The production of beetroot in the present experiment was lower than the above findings due to high temperature (air temperature ranged $27-32^{\circ} \mathrm{C}$ over the period). Beetroots require cool temperature and optimum growing temperature is $12-19^{\circ} \mathrm{C}(\mathrm{Odoh}, 2013)$.

\subsection{Proximate composition of beetroot}

The proximate compositions of beetroots were nearly similar in in $T_{1}$ and $T_{2}$ which were comparatively better than $\mathrm{T}_{0}$ except the carbohydrate content. The highest average value of lipid was $1.25 \pm 0.01$ in $\mathrm{T}_{1}$ and lowest was $1.1 \pm 0.1$ in $\mathrm{T}_{0}$. The highest mean protein and moisture contents were $0.97 \pm 0.01 \%$ and $89.46 \pm 0.58 \%$ in $\mathrm{T}_{2}$ respectively. The highest mean ash content was $0.94 \pm 0.01$ in $\mathrm{T}_{2}$ and the lowest was $0.93 \pm 0.29$ in $\mathrm{T}_{0}$. The highest mean fiber was $6.2 \pm 0.1$ in both $\mathrm{T}_{1}$ and $\mathrm{T}_{2}$ and the lowest was $5.93 \pm 0.29$ in $\mathrm{T}_{0}$. The highest mean carbohydrate was $2.1 \pm 0.72$ obtained in $\mathrm{T}_{0}$ and the lowest was $0.95 \pm 0.67$ in $\mathrm{T}_{2}$ (Table 2). Odoh et al. (2013) conducted a study on Quantitative phytochemical (proximate/nutritive) composition analysis of beetroot (Beta vulgaris) and stated that it contains $1.35,0.3,2.56,87.4$ and $1.4 \%$ of protein, fats and oils, fiber, moisture, and ash value respectively. The lipid, fiber and moisture contents were slightly higher and the percentage of protein was less 
in the present study than the above findings. However, the significantly highest nutritive value was found in $T_{1}$ and $T_{2}$ than $T_{0}$ that implies epsom salt gave the better supplementation of nutrients in $T_{1}$ and $T_{2}$.

The proximate composition was analyzed on fresh weight basis. Proximate composition of beetroot under different treatments is given in Table 2.

In this experiment, beetroots' performance was considerably better in $T_{1}$ and $T_{2}$ rather $T_{0}$. All these positive responses might be attributed to the presence of the two very crucial elements for plants' growth namely sulfur and magnesium in the supplied epsom salt (hydrated magnesium sulfate). It is well known from the literature that, magnesium helps chlorophyll formation in plants therefore aid in photosynthesis and ease nutrient uptake by plants. Although, magnesium is mostly available in the traditional soil, aquaponics plants (grown without soil) could easily suffer from magnesium deficiency and subsequent leaf curing as well as stunted growth. Similarly, sulfur regulates inner working of plants and is not as available in aquaponics substrates as in traditional soil (Kristek et al., 1997). Again, the experimental plant "beetroot" is one of the high mineral demanding plants therefore field trials (1998-2000) implied that foliar application of epsom salt with the addition of menganese and boron increased yield of sugar beets by 3-5\% (Orlovius, 2001). So, it is justified that magnesium and sulfur are to be supplied in aquaponicsally grown beetroot plants to activate plant proteins and enzymes for plants' wellbeing. Besides these, epsom salt has additional benefits on water clarification in aquaponics. Epsom salt has been reported to increase nitrate uptake of plants from fish waste water that are produced by nitrifying bacteria residing the plant root system in aquaponics (Nell et al., 2006).

\subsection{Fish growth performance and production}

During foliar application of Epsom salt the vegetable beds were kept covered with polyethylene sheet and during root (growbed) application water pumps were kept stopped for 15-20 minutes to avoid epsom salt get mixed with fish tank water. Therefore, epsom salt had negligible or no effect on fish wellbeing reared in tanks.

Tilapia (Oreochromis niloticus) was cultured for 60 days. The initial mean length of tilapia stocked in different treatments was $15.13 \pm 1.84 \mathrm{~cm}$ and final mean length were $21.30 \pm 1.60,19.17 \pm 0.44$, and $18.58 \pm 0.33 \mathrm{~cm} \mathrm{in} \mathrm{T}_{1}$, $\mathrm{T}_{2}$ and $\mathrm{T}_{0}$, respectively. The initial mean weight was $55.12 \pm 7.02 \mathrm{~g}$ that were increased up to $85.52 \pm 0.78,81.70$ \pm 0.30 , and $78.05 \pm 0.15 \mathrm{~g}$ in $\mathrm{T}_{1}, \mathrm{~T}_{2}$ and $\mathrm{T}_{0}$, respectively (Figure 3). Similarly, Bethe et al., (2017) recorded the initial mean length $9.06 \pm 1.22 \mathrm{~cm}$ and mean weight $17.27 \pm 6.50 \mathrm{~g}$ thereby after 90 days of rearing they obtained final mean length and weight of tilapia $20.83 \pm 3.04 \mathrm{~cm}$ and $187.65 \pm 81.93 \mathrm{~g}$ respectively in aquaponics system. However, Fish culture in small tank with high stocking density might be the possible reason for lower final mean length and weight in aquaponics system.

The highest mean length gain of tilapia was $5.11 \pm 1.64 \mathrm{~cm}$ in $T_{1}$ followed by $4.76 \pm 0.81$ and $3.64 \pm 1.97 \mathrm{~cm}$ in $\mathrm{T}_{2}$ and $\mathrm{T}_{0}$, respectively. Whereas, the highest mean weight gain of tilapia was $30.16 \pm 0.11 \mathrm{~g}$ in $\mathrm{T}_{1}$ followed by $26.51 \pm 0.17$ and $23.47 \pm 0.20 \mathrm{~g}$ in $\mathrm{T}_{2}$, and $\mathrm{T}_{0}$, respectively (Table 3). Bethe et al. (2017) in their 90 days of trial recorded the highest mean length gain of aquaponically grown tilapia was $11.77 \pm 2.49 \mathrm{~cm}$ and weight gain of $170.38 \pm 78.7 \mathrm{~g}$ which is higher than the present study. Zahan et al. (2018) found the mean weight gain of tilapia $295.03 \pm 12.04 \mathrm{~g}$ after 109 days of rearing which is also higher than the present study. This might be due to short culture period, high stocking density and inferior fish seed quality in the study.

The specific growth rate (SGR) of tilapia in $\mathrm{T}_{1}, \mathrm{~T}_{2}$ and $\mathrm{T}_{0}$ were $0.39 \pm 0.01,0.37 \pm 0.01$ and $0.34 \pm 0.01 \% /$ day, respectively (Table 3). In contrast, Roy et al. (2013) found that the SGR for Tilapia were $0.82,0.79$, and 0.42 $\% /$ day in three ponds which are higher than the present study. The lower SGR values in the current study might be attributed to the high stocking densities in small container, short rearing period and poor quality fish fry.

The feed conversion ratios (FCR) were 3.52, 2.87 and 3.68 found in $\mathrm{T}_{1}, \mathrm{~T}_{2}$ and $\mathrm{T}_{0}$ respectively (Table 3). Rakocy et al. (1992) and Bethe et al. (2017) obtained FCR 2.05 and 2.33 of tilapia feeding with 30\% protein containing diet. The quality of feed and associated feed loss might be responsible for comparatively higher FCR values in the present study.

At the end of the experiment total fish production was $26.27,20.08$ and 19.55 ton/ha/60 days in $T_{1}, T_{2}$ and $T_{0}$, respectively (Table 3). The present findings are lower, might be due to the aforementioned limitations of the study, than the findings of Afrin (2018) who recorded the total production of tilapia 183.1, 247.09 and 189.60 ton/ha/72 days respectively in aquaponics system. Bethe et al. (2017) also obtained 134.30 ton/ha/180 days production of tilapia from aquaponics.

However, the differences in fish growth parameters among all the three treatments were non-significant. Perhaps, it happens due to similar plant growbed quality, equal water recirculation efficacy of all aquaponics units, same species of plants and fish in all the treatments, similar fish rearing strategies, prohibition of epsom leakage into fish tanks etc. Notably, fish mortality rate was zero in all the treatments and fish growth was satisfactory in terms of length and weight, hence signifying the feasibility of aquaponics system in fish rearing. 
3.5. Water quality parameters

$\mathrm{pH}$ indicates the acidity or alkalinity of water. Water becomes acidic at a $\mathrm{pH}$ less than 7 and alkaline at a $\mathrm{pH}$ more than 7. Fish may die, if the $\mathrm{pH}$ of water reaches to 11 or more and drops to 4 or below. At the beginning of the experiment, all the fish tanks were supplied with clean tap water having $\mathrm{pH} 7.21( \pm 0.01)$. However, over the period $\mathrm{pH}$ of fish tank water varied slightly in all the treatments and finally the values were $6.49( \pm 0.03), 6.48$ $( \pm 0.01)$ and $6.53( \pm 0.05)$ in $\mathrm{T}_{1}, \mathrm{~T}_{2}$ and $\mathrm{T}_{0}$ respectively. The range of $\mathrm{pH}$ from 6.5 to 9 is the desirable range for tilapia culture. Sallenave (2016) reported that at $\mathrm{pH} 7.0$ or below, most ammonia (>96\%) remain in non-toxic form. All these references verify the suitable $\mathrm{pH}$ ranges of the fish holding tank in the experiment.

EC (electric conductivity) is a measure of total nutrients contained in water. Initially the EC value of fish tank water was $747.33( \pm 0.01)$ that increased over the period in all the treatments. On the final sampling, the highest EC value was $1521.0( \pm 59.40) \mu \mathrm{s} / \mathrm{cm}$ found in $\mathrm{T}_{1}$ and the lowest value of EC $1302.33( \pm 187.79) \mu \mathrm{s} / \mathrm{cm}$ was found in $\mathrm{T}_{0}$. Bablee et al., 2019 showed the $\mathrm{EC}$ ranged between 747-1388.5 $\pm 26.27 \mu \mathrm{s} / \mathrm{cm}$ in aquaponics system. The observed EC implies usual range for aquaponics system.

The mean values of carbonate were $4.0( \pm 1.14)$ and $32.67( \pm 2.67) \mathrm{mg} / \mathrm{l}$ observed in $\mathrm{T}_{2}$ and $\mathrm{T}_{0}$ respectively at the end of the experiment. Whereas carbonate was absent in $T_{1}$. Boyd (1990) mentioned that acceptable carbonate range in pond aquaculture is $0-20 \mathrm{mg} / \mathrm{l}$. So it could be concluded that $\mathrm{CO}_{3}$ range was within the suitable range for fish culture in the experiment.

Initially, the hydrogen carbonate value started from $286.73( \pm 0.01) \mathrm{mg} / \mathrm{l}$ in all the treatments and decreased with the passing of time. This decrease was probably due to the accelerating plants and fish growth in the system irrespective to treatments. However, during the final sampling the highest hydrogen carbonate value was 167.00 $( \pm 9.24) \mathrm{mg} / \mathrm{l}$ found in $\mathrm{T}_{0}$ and the lowest value was $126.50( \pm 13.17) \mathrm{mg} / \mathrm{l}$ in $\mathrm{T}_{1}$. Therefore, beetroot plants in $\mathrm{T}_{1}$ were more active in ionic utilization than other treatments. Boyd (1990) mentioned that acceptable hydrogen carbonate range in pond aquaculture is $50-300(\mathrm{mg} / \mathrm{l})$. So, it can be concluded that hydrogen carbonates in the experimental fish tanks were within acceptable range over the study period.

During final sampling of fish tank water, the highest total $\mathrm{N}$ value $8.86( \pm 2.91) \mathrm{mg} / \mathrm{l}$ was found in $\mathrm{T}_{0}$ and the lowest in $\mathrm{T}_{1}$ counted as $6.5( \pm 0.80) \mathrm{mg} / \mathrm{l}$, whereas, the highest value of total- $\mathrm{N}$ was $16.35 \pm 0.64 \mathrm{mg} / \mathrm{l}$ estimated by Salam et al. (2014) in aquaponics system. The amount of total-N in individual tank water was lower than the above findings. This was because the absorption rate of nitrogen by beetroot plants from fish waste water in the form of nitrates was enhanced with magnesium and sulfur supplementation through epsom salt (Nell et al., 2006),. However the observed values of total $\mathrm{N}$ in fish tanks comply the suitable range for fish culture (Boyd, 1990).

However, other nutrients such as phosphorus $(\mathrm{P})$, sulfur $(\mathrm{S})$, sodium $(\mathrm{Na})$ and potassium $(\mathrm{K})$ contents in fish tanks' water were within acceptable ranges for aquaculture (Boyd, 1990).

Water temperature is a very crucial parameter for maintaining normal physiological process in fish body and could strongly affect aquaculture production (León et al., 2006). Throughout the study, water temperature varied among different treatments likewise 22.9 to $27.4,24.2$ to 28.2 and 25.4 to $28.5^{\circ} \mathrm{C}$ in $\mathrm{T}_{1}, \mathrm{~T}_{2}$ and $\mathrm{T}_{0}$ respectively (Figure 5). According to Losordo et al. (1998) a wide range of 25 to $32^{\circ} \mathrm{C}$ temperature gave acceptable growth rates for tilapia and nitrification can also be accomplished between 15 to $25^{\circ} \mathrm{C}$ while undisturbed to $30^{\circ} \mathrm{C}$. Therefore, fish in tanks and nitrifying bacteria residing the root system of beetroot plants were quite comfortable for performing their activities (Tyson et al., 2004).

Dissolved oxygen (DO) concentration of culture water can lead to stressful condition for fish if not present adequately. DO of $5 \mathrm{ppm}$ in water is the best condition for fish growth and it is hampered if kept below $5 \mathrm{ppm}$ for long time (Boyd, 1990). With the use of aerator in fish tanks, the dissolved oxygen (DO) concentration was remained well above $5 \mathrm{ppm}$ in all the treatments whereas the highest mean DO of $8.2 \mathrm{ppm}$ was recorded in $\mathrm{T}_{2}$. So, the DO contents of tank water were within the acceptable limit for fish (Figure 5).

The toxic elements ( mostly ammonia and nitrite) in fish tank water, produced from fish excreta and feed wastes, were subjected to nitrification by autotrophic nitrifying bacteria (primarily Nitrosomonas and Nitribacter) harboring the plant root system in aquaponics while passing the tank water through aquaponics growbeds (Tyson et al., 2004; Haug and McCarty, 1972). The final result is the transformation of toxic ammonia and nitrites into plant usable nitrates. This process keeps the tank water livable for fish and supply nutrients to the plants grown in soilless media (aquaponics). The maximum ammonia was recorded in $\mathrm{T}_{1}$ followed by $\mathrm{T}_{2}$ and $\mathrm{T}_{0}$ on 16 May, 2018 (Figure 4). The maximum nitrite and nitrate were found in $\mathrm{T}_{1} 0.73 \pm$ 0.15 and $39.56 \mathrm{ppm}$ respectively. The acceptable range of ammonia, nitrite and nitrate in aquaponics system are $<1 \mathrm{ppm},<1 \mathrm{ppm}, 5-150 \mathrm{ppm}$ (Sallenave, 2016). So, it can be concluded that the ammonia, nitrite and nitrate contents of tank water were tolerable for fish. 
Table 1. Growth parameters of beetroot plants after final harvesting.

\begin{tabular}{|c|c|c|c|c|c|c|c|}
\hline Treatments & $\begin{array}{l}\text { Length of } \\
\text { roots }(\mathrm{cm})\end{array}$ & $\begin{array}{l}\text { Wt. of } \\
\text { roots } \\
(\mathrm{g})\end{array}$ & $\begin{array}{l}\text { Wt. of } \\
\text { leaves } \\
(\mathrm{g})\end{array}$ & $\begin{array}{l}\text { Wt. of } \\
\text { beetroot } \\
\text { (g) }\end{array}$ & $\begin{array}{l}\text { Length of } \\
\text { plant } \\
(\mathbf{c m})\end{array}$ & $\begin{array}{l}\text { Weight of } \\
\text { plant } \\
\text { (g) }\end{array}$ & $\begin{array}{l}\text { Production } \\
\text { (tons/ha/ } \\
\text { 90days) }\end{array}$ \\
\hline $\mathbf{T}_{1}$ & $\begin{array}{l}31.03 \\
( \pm 0.43)^{\mathrm{a}}\end{array}$ & $\begin{array}{l}21.17 \\
( \pm 1.92)^{\mathrm{a}}\end{array}$ & $\begin{array}{l}41.91 \\
( \pm 2.41)^{\mathrm{a}}\end{array}$ & $\begin{array}{l}95.28 \\
( \pm 6.40)^{\mathrm{a}}\end{array}$ & $\begin{array}{l}64.81 \\
( \pm 2.65)^{a}\end{array}$ & $\begin{array}{l}160.11 \\
( \pm 1.51)^{\mathrm{a}}\end{array}$ & $\begin{array}{l}8.67 \\
( \pm 1.43)^{\mathrm{a}}\end{array}$ \\
\hline $\mathbf{T}_{2}$ & $\begin{array}{l}26.05 \\
( \pm 1.58)^{b}\end{array}$ & $\begin{array}{l}18.73 \\
( \pm 1.91)^{\mathrm{b}}\end{array}$ & $\begin{array}{l}39.43 \\
( \pm 2.25)^{\mathrm{a}}\end{array}$ & $\begin{array}{l}80.58 \\
( \pm 3.09)^{b}\end{array}$ & $\begin{array}{l}59.17 \\
( \pm 4.75)^{\mathrm{a}} \\
\end{array}$ & $\begin{array}{l}136.58 \\
( \pm 4.68)^{b}\end{array}$ & $\begin{array}{l}7.48 \\
( \pm 2.71)^{b}\end{array}$ \\
\hline $\mathbf{T}_{\mathbf{0}}$ & $\begin{array}{l}19.48 \\
( \pm 1.63) \mathrm{c}\end{array}$ & $\begin{array}{l}14.24 \\
( \pm 1.01)^{\mathrm{c}}\end{array}$ & $\begin{array}{l}31.08 \\
( \pm 3.11)^{b}\end{array}$ & $\begin{array}{l}73.87 \\
( \pm 2.71)^{b}\end{array}$ & $\begin{array}{l}43.68 \\
( \pm 1.71) \mathrm{b}\end{array}$ & $\begin{array}{l}129.06 \\
( \pm 3.05) \mathrm{b}\end{array}$ & $\begin{array}{l}6.61 \\
( \pm 1.82)^{b}\end{array}$ \\
\hline P-Value & 0.001393 & 0.0008763 & 0.02396 & 0.01271 & 0.00678 & 0.00103 & .012 \\
\hline $\begin{array}{ll}\text { Level } & \text { of } \\
\text { Significant } & \end{array}$ & $* *$ & $* * *$ & $*$ & $*$ & $* *$ & $* *$ & $* *$ \\
\hline CV $(\%)$ & 5.475 & 4.16 & 3.934 & 5.74 & 4.18 & 2.546 & 1.65 \\
\hline
\end{tabular}

In a column, figures with same letters or without letter do not differ significantly whereas figures with dissimilar letter differ significantly as per Duncan's New Multiple Range Test (DMRT).

$*$ = Significant at $5 \%$ level of probability

$* *=$ Significant at $1 \%$ level of probability

$* * *=$ Significant at $0.1 \%$ level of probability

Table 2. Proximate composition of beetroot.

\begin{tabular}{|c|c|c|c|c|c|c|}
\hline Treatment & Protein $(\%)$ & Lipid (\%) & Fiber $(\%)$ & $\begin{array}{l}\text { Ash } \\
(\%)\end{array}$ & $\begin{array}{l}\text { Moisture } \\
\text { (\%) }\end{array}$ & $\begin{array}{l}\text { Carbohydrate } \\
(\%)\end{array}$ \\
\hline $\mathrm{T}_{1}$ & $\begin{array}{l}0.94 \\
( \pm 0.015)^{b}\end{array}$ & $\begin{array}{l}1.25 \\
( \pm 0.015)^{\mathrm{a}}\end{array}$ & $\begin{array}{l}6.2 \\
( \pm 0.1)^{\mathrm{a}}\end{array}$ & $\begin{array}{l}0.92 \\
( \pm 0.015)^{\mathrm{a}}\end{array}$ & $\begin{array}{l}89.7 \\
( \pm 0.59) \mathrm{a}\end{array}$ & $\begin{array}{l}1.67 \\
( \pm 0.84) b\end{array}$ \\
\hline $\mathrm{T}_{2}$ & $\begin{array}{l}0.97 \\
( \pm 0.013)^{\mathrm{a}}\end{array}$ & $\begin{array}{l}1.23 \\
( \pm 0.015)^{\mathrm{ab}}\end{array}$ & $\begin{array}{l}6.2 \\
( \pm 0.1)^{\mathrm{a}}\end{array}$ & $\begin{array}{l}0.94 \\
( \pm 0.01)^{\mathrm{a}}\end{array}$ & $\begin{array}{l}89.46 \\
( \pm 0.58) b\end{array}$ & $\begin{array}{l}0.95 \\
( \pm 0.67) \mathrm{c}\end{array}$ \\
\hline $\mathrm{T}_{0}$ & $\begin{array}{l}0.91 \\
( \pm 0.01)^{\mathrm{c}}\end{array}$ & $\begin{array}{l}1.1 \\
( \pm 0.1)^{b}\end{array}$ & $\begin{array}{l}5.93 \\
( \pm 0.015)^{b}\end{array}$ & $\begin{array}{l}0.93 \\
( \pm 0.29)^{\mathrm{a}}\end{array}$ & $\begin{array}{l}89.00 \\
( \pm 0.89) \mathrm{c}\end{array}$ & $\begin{array}{l}2.1 \\
( \pm 0.72) a\end{array}$ \\
\hline $\mathrm{P}$ value & 0.0017 & 0.028 & 0.011 & 0.29 & .00025 & .000013 \\
\hline Level of significance & $* *$ & $* *$ & $*$ & NS & $* * *$ & $* * *$ \\
\hline $\mathrm{CV}(\%)$ & 0.85 & 5.06 & 1.04 & 12.57 & 0.06 & 3.49 \\
\hline
\end{tabular}

In a column, figures with same letters or without letter do not differ significantly whereas figures with dissimilar letter differ significantly as per Duncan's New Multiple Range Test (DMRT).

$*=$ Significant at $5 \%$ level of probability

$* *=$ Significant at $1 \%$ level of probability

$* * *=$ Significant at $0.1 \%$ level of probability

$\mathrm{NS}=$ non significant

Table 3. Growth performances of tilapia in aquaponics system of the experiment.

\begin{tabular}{|c|c|c|c|c|c|c|c|c|}
\hline Treatments & $\begin{array}{l}\text { Mean } \\
\text { length } \\
\text { gain } \\
(\mathrm{cm}) \\
\end{array}$ & $\begin{array}{l}\text { Mean } \\
\text { weight } \\
\text { gain (g) }\end{array}$ & $\begin{array}{l}\text { Percent } \\
\text { length } \\
\text { gain }(\%)\end{array}$ & $\begin{array}{l}\text { Percent } \\
\text { weight } \\
\text { gain }(\%)\end{array}$ & $\begin{array}{l}\text { Survival } \\
(\%)\end{array}$ & $\begin{array}{l}\text { Specific } \\
\text { growth } \\
\text { rate }(\%) \\
\text { per day }\end{array}$ & FCR & $\begin{array}{l}\text { Production } \\
\text { (ton/ha/60 } \\
\text { days) }\end{array}$ \\
\hline $\mathbf{T}_{1}$ & $\begin{array}{l}5.11 \\
( \pm 1.64)^{\mathrm{a}}\end{array}$ & $\begin{array}{l}30.16 \\
( \pm 0.11)^{\mathrm{a}}\end{array}$ & $\begin{array}{l}36.62 \\
( \pm 5.00)^{\mathrm{a}}\end{array}$ & $\begin{array}{l}53.15 \\
( \pm 0.27)^{\mathrm{a}}\end{array}$ & $\begin{array}{l}76.66 \\
( \pm 0.19)^{\mathrm{a}}\end{array}$ & $\begin{array}{l}0.39 \\
( \pm 0.01)^{\mathrm{a}}\end{array}$ & $\begin{array}{l}3.52 \\
( \pm 0.01)^{\mathrm{a}}\end{array}$ & $\begin{array}{l}26.27 \\
( \pm 2.47)^{\mathrm{a}}\end{array}$ \\
\hline $\mathbf{T}_{2}$ & $\begin{array}{l}4.76 \\
( \pm 0.81)^{\mathrm{a}}\end{array}$ & $\begin{array}{l}26.51 \\
( \pm 0.17)^{\mathrm{a}}\end{array}$ & $\begin{array}{l}31.33 \\
( \pm 7.31)^{\mathrm{a}} \\
\end{array}$ & $\begin{array}{l}46.11 \\
( \pm 0.20)^{\mathrm{a}}\end{array}$ & $\begin{array}{l}73.33 \\
( \pm 0.31)^{\mathrm{a}} \\
\end{array}$ & $\begin{array}{l}0.37 \\
( \pm 0.01)^{\mathrm{a}}\end{array}$ & $\begin{array}{l}2.98 \\
( \pm 0.01)^{\mathrm{a}}\end{array}$ & $\begin{array}{l}20.08 \\
( \pm 1.87)^{\mathrm{a}}\end{array}$ \\
\hline $\mathbf{T}_{\mathbf{0}}$ & $\begin{array}{l}3.90 \\
( \pm 1.97)^{\mathrm{a}}\end{array}$ & $\begin{array}{l}23.47 \\
( \pm 0.20)^{\mathrm{a}}\end{array}$ & $\begin{array}{l}28.91 \\
( \pm 4.53)^{a}\end{array}$ & $\begin{array}{l}43.86 \\
( \pm 0.21)^{\mathrm{a}}\end{array}$ & $\begin{array}{l}66.66 \\
( \pm 0.51)^{a}\end{array}$ & $\begin{array}{l}0.34 \\
( \pm 0.01)^{a}\end{array}$ & $\begin{array}{l}3.68 \\
( \pm 0.01)^{\mathrm{a}}\end{array}$ & $\begin{array}{l}19.55 \\
( \pm 1.56)^{\mathrm{a}}\end{array}$ \\
\hline P-Value & 0.57 & 0.17 & 0.32 & 0.33 & 0.28 & 0.12 & 0.63 & 0.65 \\
\hline $\begin{array}{l}\text { Level of } \\
\text { Significant }\end{array}$ & NS & NS & NS & NS & NS & NS & NS & NS \\
\hline $\mathrm{CV}(\%)$ & 8.80 & 6.60 & 4.71 & 9.14 & 6.22 & 4.78 & 0.78 & 5.94 \\
\hline
\end{tabular}

In a column, figures with same letters or without letter do not differ significantly whereas figures with dissimilar letter differ significantly as per Duncan's New Multiple Range Test (DMRT).

$\mathrm{NS}=$ non significant 

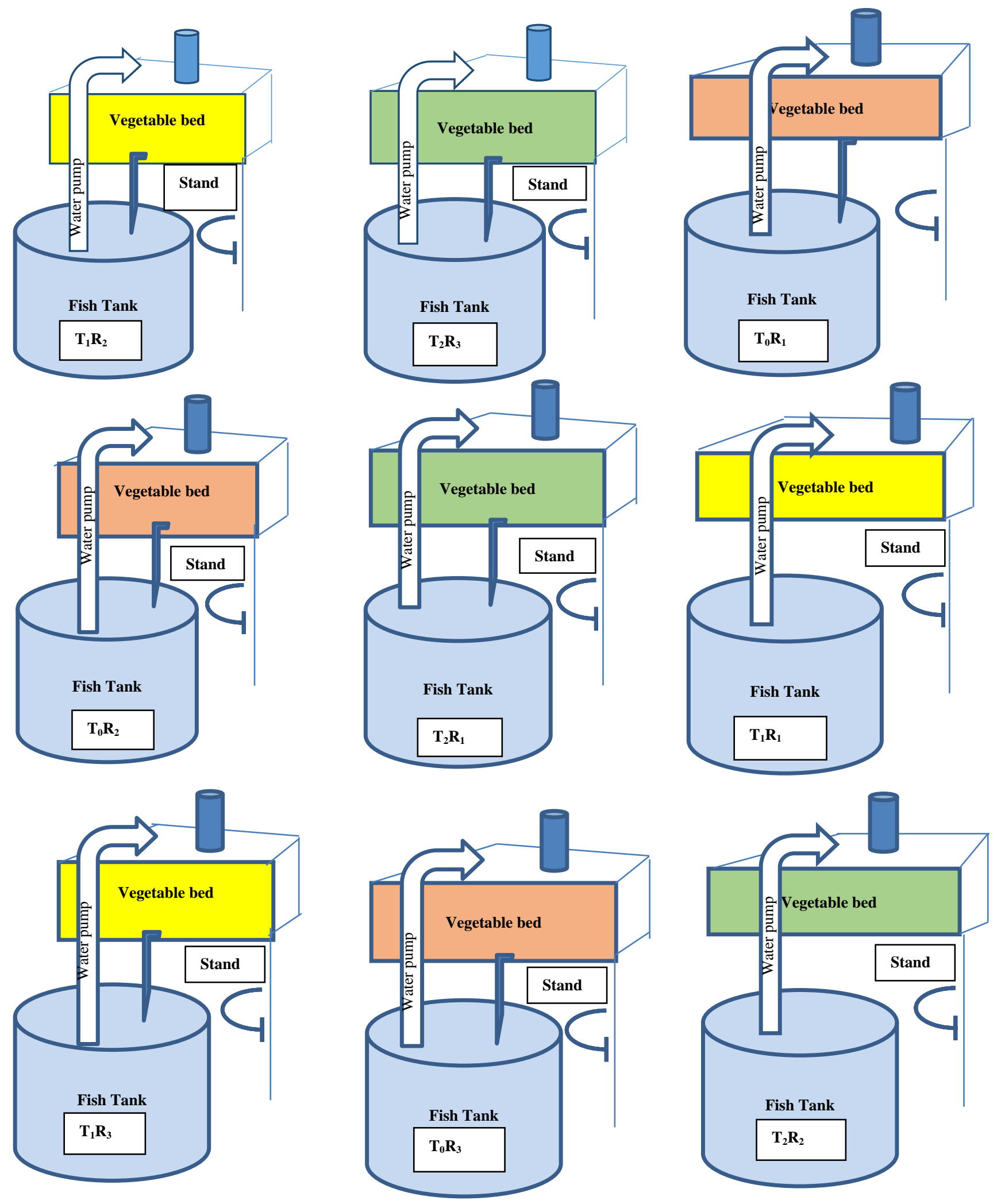

Figure 1. Experimental design. 


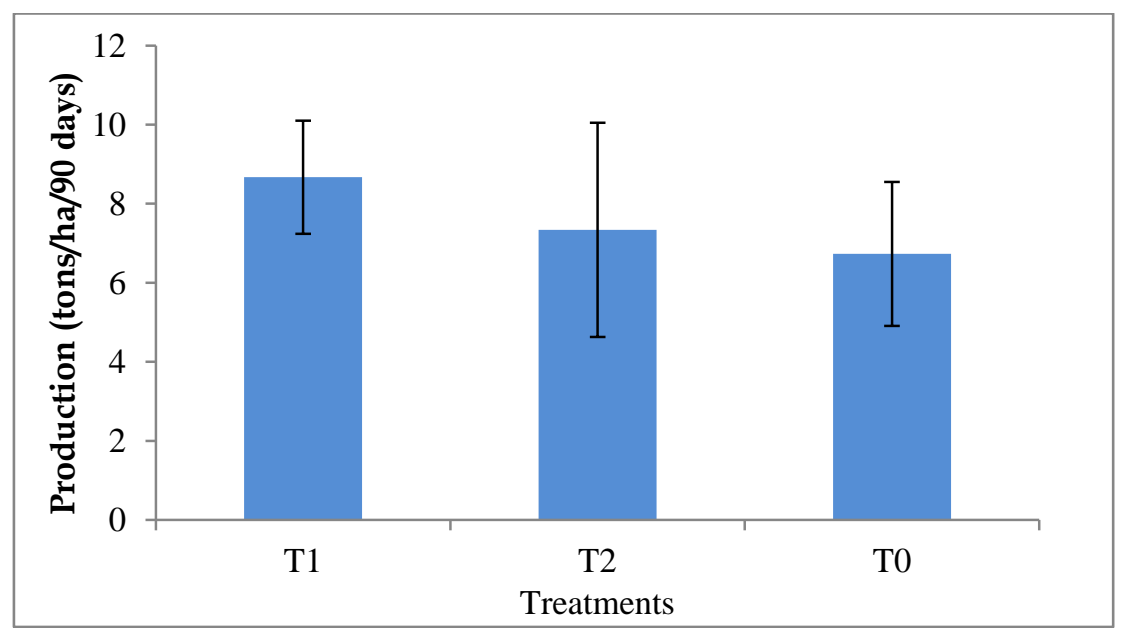

Figure 2. Production of beetroot (ton \pm SD) over the study period. Vertical bar of each treatment represents standard deviation.

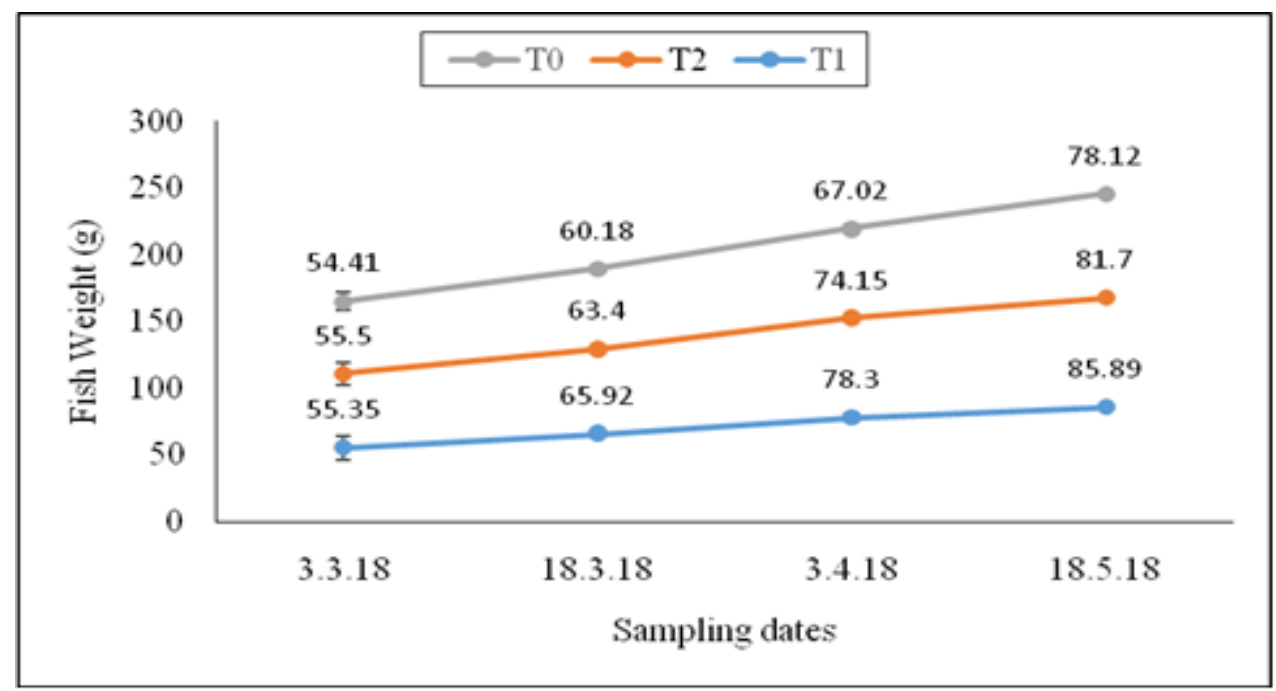

Figure 3. Weight of tilapia in different treatments on different sampling dates.

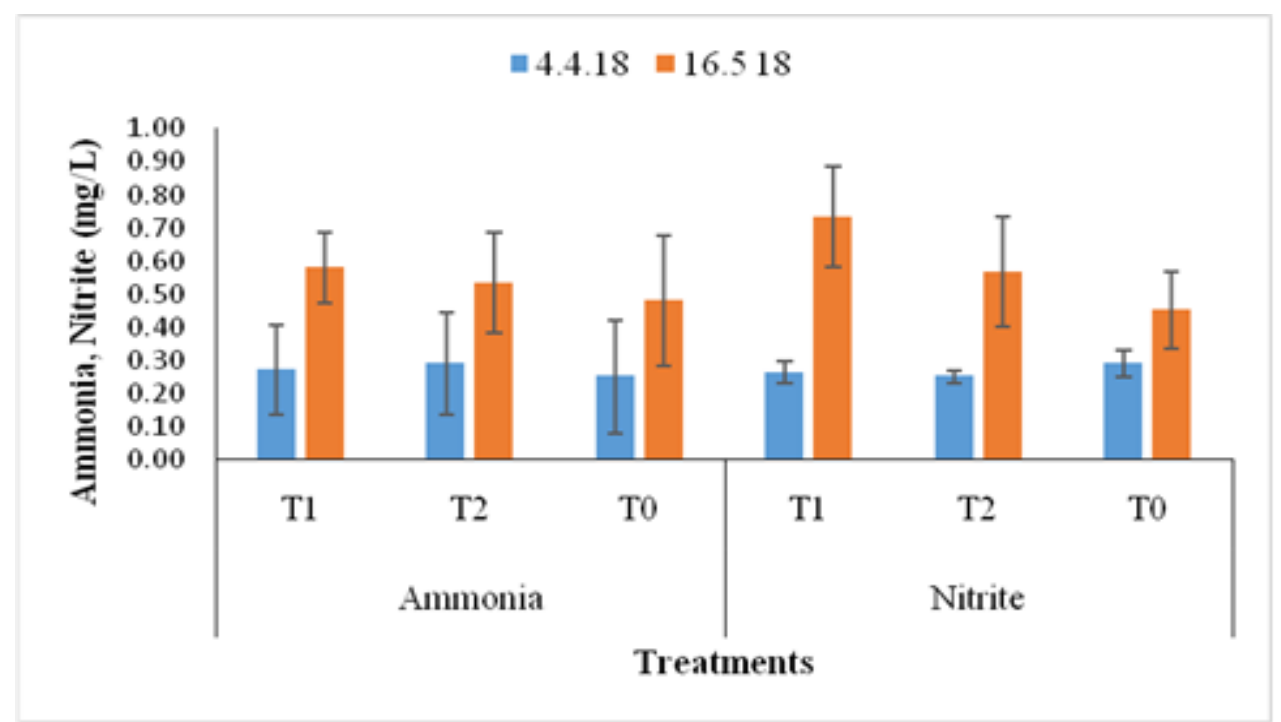

Figure 4. Ammonia and nitrite contents of fish tank water during the study period. Vertical bar of each treatment represents standard deviation (SD). 


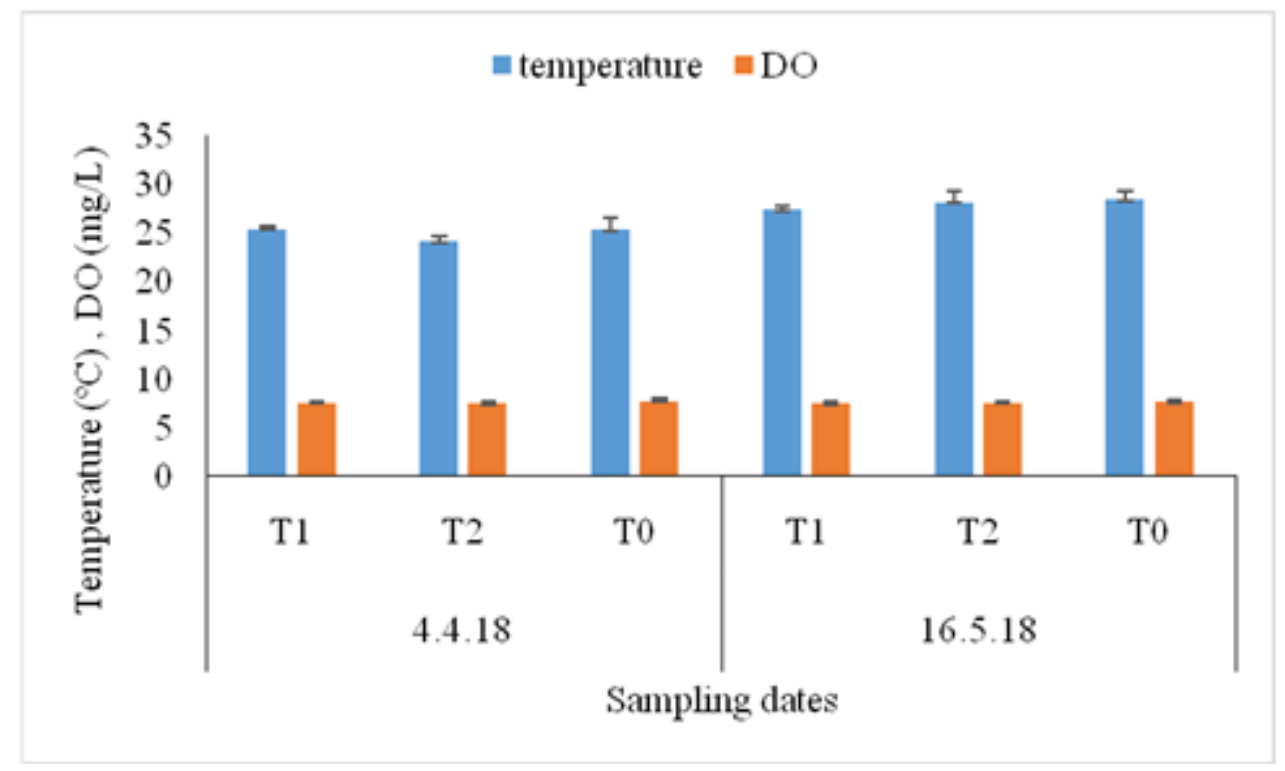

Figure 5. Water temperature and dissolved oxygen (DO) contents of fish tank water. Vertical bar of each treatment represents standard deviation (SD).

\section{Conclusions}

Magnesium and sulfur are the two very crucial minerals for plant growth. Although they are quite available in the agricultural lands, aquaponically grown vegetables might require to be supplemented with these nutrients as they lack soil contact. This experiment has used epsom salt as the primary supplier of magnesium and sulfur to beetroot in aquaponics system with a view to summarizing its effect on plants' growth without hampering the fish well being. Growth and production of beetroot was better in $\mathrm{T}_{1}$ (epsom salt as foliar spray) than $\mathrm{T}_{2}$ (epsom salt as root application) and $\mathrm{T}_{0}$ (control), which might favor to conclude that addition of epsom salt supplied maximum minerals and nutrients to the plants. In the present experiment, beetroot was appeared in epsom salt based aquaponics system 15 days earlier than $\mathrm{T}_{0}$. Therefore, it may be stated that epsom salt has a significant role in decreasing the harvesting period and increasing production of beetroot in aquaponics. However, in depth research is needed to verify the effects and dose response to epsom salt in aquaponics system supplemented as plant growth promoter.

\section{Conflict of interest}

None to declare.

\section{References}

Afrin R, 2018. Cauliflower (Brassica oleracea) production incorporated with sea salt in aquaponics system. European J. Biotechnol. Biosci., 6: 05-11.

Anna A and GA Maria, 2013. Comparison of yield and quality of red beetroots cultivated using conventional, integrated and organic method. J. Hort. Res., 21: 107-114.

Azad KN, 2015. Comparative study of okra production using different bedding media in aquaponics system, MS Thesis, Department of Aquaculture, Bangladesh Agricultural University, Mymensingh, Bangladesh. pp. 102.

Azad KN, MA Salam and KN Azad, 2016. Aquaponics in Bangladesh: current status and future prospects. J. Biosci. Agric.Res., 7: 669-677.

Bablee A, KMS Rana and MA Salam, 2019. Effects of aspirin on aquaponics tomato (Solanum lycopersicum) production in laboratory condition. Asian J. Med. Biol. Res., 5: 78-86.

Bethe LA, MA Salam, UK Fatema and KMS Rana, 2017. Effects of molasses and compost tea as foliar spray on water spinach (Ipomoea aquatica) in aquaponics system. Int. J. Fish. Aquat. Stud., 5: 203-207.

Boyd CE, 1990. Water quality in ponds for aquaculture. Auburn University, Auburn, Alabama, USA. pp. 482.

Chawla H, M Parle, K Sharma and M Yadav, 2016. Beetroot: A Health Promoting Functional Food. Inventi Impact: Nutraceuticals., 2016: 8-12.

Elamin OM and GE Wilcox, 1985. Effect of magnesium fertilization on yield and leaf composition of tomato plants. J. Plant Nutri., 8: 999-1012. 
Elbossaty WF, 2018. Pharmaceutical Influences of Epsom Salts. American Journal of Pharmacology and Pharmacotherapeutics., 5: 2.

Epstein E and AJ Bloom, 2005. Mineral Nutrition of Plants: Principles and Perspectives, 2nd Edn. Sinauer Associates, Incorporated, Sunderland, MA, USA.

Haug RT and PL MCCarty, 1972. Nitrification with submerged filters. J. Water Pollut. Control Fed., 44: 20-86.

Kristek A, E Andres, V Kovacevic, I Liovic and M Rastija, 1997. Response of sugar beet to foliar fertilization with Epsom salt $\left(\mathrm{MgSO}_{4} .7 \mathrm{H}_{2} \mathrm{O}\right)$. In: Ando T., Fujita K., Mae T., Matsumoto H., Mori S., Sekiya J. (eds) Plant Nutrition for Sustainable Food Production and Environment. Developments in Plant and Soil Sciences, vol 78. Springer, Dordrecht.

León CJ, JM Hernández and M León-Santana, 2006. The effects of water temperature in aquaculture management. J. Appl. Econ., 38: 2159-2168.

Losordo TM, MP Massar and J Rakocy, 1998. Recirculating aquaculture tank production systems. An overview of critical considerations. Southern Region Aquaculture Center (SRAC), Publication No. 451.

Maathuis FJM, 2009. Physiological functions of mineral macronutrients. Curr. Opin. Plant Biol., 12: 250-258.

Merhaut DJ, 2007. Handbook of plant nutrition. CRC Press, Boca Raton, FL, USA, pp. 145-182.

Nell IM and P Rathy, 2006. Effect of magnesium fertilizers on total glycoalkaloids and nitrate-N in katahdin tubers. J. Food Sci., 50: 535-536.

Tilley N, 2016 November 27. Information About Using Epsom Salts For Plants. Retrieved from https://www.gardeningknowhow.com

Ninfali P and D Angelino, 2013. Nutritional and functional potential of Beta vulgaris cicla and rubra. Fitoterapia, 89: 188-199.

Obatolu CR, 1999. Correction of magnesium deficiency in tea plants through foliar applications. Commun. Soil Sci. Plan.,30:1649-1655.

Odoh UE and EC Okoro, 2013. Quantitative phytochemical, proximate/nutritive composition analysis of Beta vulgaris Linnaeus (Chenopodiaceae). Int. J.curr. res., 5: 3723-3728.

Orlovius K, 2001. Effect of foliar fertilization with magnesium, sulfur, manganese and boron to sugar beet, oilseed rape, and cereals. In: Horst W.J.et al., (eds) Plant Nutrition. Developments in Plant and Soil Sciences, vol 92. Springer, Dordrecht. pp. 788-789.

Parvin T, 2016. Growth and performance of taro (Colocasiaesculenta) in aquaponics system in laboratory condition, MS Thesis, Department of Aquaculture, Bangladesh Agricultural University, Mymensingh. pp. 95.

Rakocy JE, TM Losordo and MP Masser, 1992. Recirculating aquaculture tank production systems. Integrating Fish and Plant Culture. Southern Region Aquaculture Center (SRAC), Publication No. 454.

Rakocy JE, DS Bailey, RC Shultz and JJ Danaher, 2011. A commercial-scale aquaponics system developed at the University of the Virgin Islands. Proceedings of the $9^{\text {th }}$ international symposium on Tilapia in Aquaculture, pp. 22-24.

Roy M, 2012. Feasibility study of aquaponics in polyculture pond, MS Thesis, Department of Aquaculture, Bangladesh Agricultural University, Mymensingh. pp. 83.

Salam MA, N Jahan, S Hashem and KMS Rana, 2014. Feasibility of tomato production in aquaponics system using different substrates. Progress. Agric., 25: 54-62.

Sallenave R, 2016. Important Water Quality Parameters in Aquaponics Systems. Circular 680. The College of Agricultural, Consumer and Environmental Sciences on the World Wide Web at aces.nmsu.edu. pp. 1-7.

Tyson RV, EH Simon, JM White and EM Lamb, 2004. Reconciling water quality parameters impacting nitrification in aquaponics: The pH levels. Proceeding of the Florida State Horticulture Society., 117: 79-83.

Yildiz Y, L Robaina, J Pirhonen, E Mente, D Dominguez and G Parisi, 2017. Fish welfare in aquaponics systems: its relation to water quality with an emphasis on feed and faeces- a review. Water, 9: 13.

Zahan S, KMS Rana, MK Islam, T Islam and MA Salam, 2018. Impact of calcium suppliments through egg shell on tomato (Solanum lycopersicum) production in Aquaponics System. Int. J. App. Res., 4: 134-139. 